\title{
Reviewing horizontalization: the challenge of analysis in Brazilian foreign policy
}

Revisando a horizontalização:

o desafio da análise da Política Externa Brasileira

http://dx.doi.org/10.1590/0034-7329201500201

ROGÉRIO DE SOUZA FARIAS*

HAROLDO RAMANZINI JÚNIOR**

Rev. Bras. Polít. Int. 58 (2): 5-22 [2015]

\section{Introduction}

In the last decades of the 20th century, Latin American "became more democratic than ever before". The pace of change made Paul W. Drake call these regimes "tsunami democracies". Swept by this wave, optimism was widespread. But it soon withered. Disgruntling became visible and a growing chasm opened between the formal structure of contemporary democracy in the region and how citizens felt about their governments. Many were considered "elitist, autocratic, centralized, presidential, personalistic, clientelistic, incompetent, and corrupt" (Drake 2009, 201 and 205). Academic pundits responded to this situation in an innovative way. O'Donnell points out the transition "from a democratically elected government to an institutionalized, consolidated democratic regime" as the necessary step towards maturity and stabilization in the region. Delegative democracy - "the premise that whoever wins elections to the presidency is thereby entitled to govern as he or she sees fit" - had to give way to more political rights (O'Donnell 1994, 56; O’Donnell: 2001). In this understanding, the analysis of the democratic wave in Latin America had to look not only to the formal aspects of the democratic regime - freedom of the press, rule of law, periodic elections and separation of powers - but also to the institutional milieu that fosters everyday links between citizen's preferences and government public policies. It was through the "new modes of institutionalized participation" (Córdova 2015, 155) of society that Latin American democracies would ditch the last remains of authoritarianism and embrace a new phase in their political history.

* University of Chicago, Center for Latin American Studies, Chicago, United States (rofarias@gmail.com).

** Universidade Federal de Uberlândia, Instituto de Economia, Uberlândia-MG, Brazil (hramanzinijunior@gmail.com). 
The conceptual focus on political participation in Latin America is certainly not new. In the 1970s, John A. Booth and Mitchell A. Seligson organized a book on the theme, using the concept of participation as "behavior influencing or attempting to influence the distribution of public goods" (Booth and Seligson 1978, 6). Since then, the field has been connecting the theoretical research on participatory democracy with more narrow attempts to understand how participation occurs in particular public policies. The literature has tried hard to conceive and use the concept of participation (Oxhorn 2012, 249; Walker 2013, 222), and to expand its observations from specific policies for human rights, housing, environment and budgeting 1 .

In this article we will focus on the debate about participatory democratization in Brazilian foreign policy. This case is important for five reasons. First, the end of Cold War and the democratization process brought great optimism about changes in state accountability and broader participation in the decision-making process (Muñoz and Tulchin 1984; Lijphart and Waisman 1996). Foreign policy, traditionally conceived as a field impervious to participation from society, particularly in Brazil, became more democratic, according to some early examinations (Barros 1984; Hirst 1996). Observing, after this early period, how responsive this area became to the democratization wave in Latin America will show how far the new architecture of state-society relations affected strategic policymaking activities. Second, in the last decades society and markets integrated in multiples and unexpected ways. Most policy arenas seem to be affected by transnational networks of activists, companies and international organizations. If local policy arenas are now part of a global struggle for shaping rules, it is relevant to understand how society affects it. Third, probably as a result of the previous aspect, new organizations (both public and private) have been challenging the autonomy of diplomats. If that is the case, the multiple channels through which citizens could shape agenda and decisions would increase - something that would strengthen participatory democracy. Fourth, although we have a trove of studies about the quest of American foreign policy to promote democratization in Latin America ${ }^{2}$, few studies approach the nature of the foreign policymaking machinery in the region ${ }^{3}$. Fifth, there is a growing literature indicating that despite great efforts to expand the engagement of Brazilian society in public policies, Lula's

1 The last field is particularly relevant. See, for example: Santos 2005; Aragonès e Sánchez-Pagés 2009; Castro, Ferreira, Junior and Cardoso 2011; Avritzer 2009; Brasil, Carneiro, Barbosa and Almeida 2013; Eubanks 2007; Wampler 2012; Fuks 2005; Córdova 2015.

2 In this contribution we will not dwell in the relationship between the quest of American foreign policy to promote democratization in Latin, and the democratization of the foreign policy process in Brazil and Latin America.

3 A few studies examine American foreign policy directly, while others study the influence of specific policies, like international aid. For a summary, refer to Knack 2004; Levitsky and Way 2005; Youngers and Rosin 2005; Carothers 1991; Lowenthal 1991. In the most recent contribution so far about foreign policy analysis in Latin America, the theme is not evaluated at all (Giacalone 2012). 
administration (2003-2010) failed to revamp state structures ${ }^{4}$. It is important to understand whether the foreign policy arena evolved in the same way.

Our approach here is first to present the literature on the participation of citizens and bureaucracies in Brazilian foreign policy. These works usually use the term "horizontalization" to talk about the democratization of the policy arena in the government (more ministries) and also the engagement of citizens. In the third section, we will assess the thesis of horizontalization regarding the five aspects: conceptual accuracy, comparison parameters, empirical basis, use of sources and role of systemic forces. This discussion will be followed by relevant theoretical and methodological analysis. Using the case of the Brazilian Ministry of Foreign Affairs (Itamaraty), we will argue that the democratization of the political regime does not lead necessarily to democratization of the decision-making process. This confirms Philippe C. Schmitter's argument that democratization can have several outcomes (Schmitter 1995, 15-17). Finally, in the conclusion, we will suggest a future research agenda.

We intend, in this article, to contribute to the debate on democratization and Brazilian foreign policy. This contribution, though, will be in the narrow theoretical and methodological field. We will defend the need to overcome problems related to: 1) conceptual vagueness about what the concept of participation means; 2) lack of clarity in the baseline to which comparisons are made; 3) fragile empirical basis; 4) limitations on the use of sources; and 5) how to understand the impact exerted by systemic forces.

\section{Democratization as horizontalization}

As a field of study, Brazilian Foreign Policy Analysis has grown significantly in recent years. Generally, these studies conclude that following the general trend of democratization in the political regimes, there was a broader pluralism in the foreign policy arena - a process in which the Brazilian Ministry of Foreign Affairs (Itamaraty) lost some of its power. In Brazil, besides the term horizontalization (França and Badin 2010; Campos Lima 2012), scholars use terms like "decentralization" (Spécie 2008) "pluralization" (Cason and Power 2009), "decapsuling" (Faria 2008), "politicization”, "democratization”(Armijo and Kearney 2008), "power shift" (Vieira 2013) and "diversification of interests"(Milani and Pinheiro 2012) to characterize what they consider to be the current situation, in contrast to an earlier period, when the decision-making process would have been characterized by insulation or verticalization. To justify the policy change, these studies project a past quite different from the current situation. One example of this perspective is a contribution by Sean W. Burges. In a recent review, he stated:

4 A good review of this argument was recently presented by Hernán F. Gómez Bruera (2015). 
Brazilian foreign policy has reached a very interesting inflection point. The bureaucratic walls of the Itamaraty Palace so stoutly erected by the Baron of Rio Branco in 1902 are cracking. Where foreign policy used to be neatly circumscribed by the world of 'high politics' and external interaction by Brazilians limited to a small group of clearly defined actors, the situation today is very different. Itamaraty retains pride of place for the grand geopolitical thinking that often preoccupies the study of foreign policy, but the aspects of international affairs touching the lives of citizens everywhere are increasingly becoming the concern of line ministries, subnational governments, state agencies and private actors (Burges 2013, 171-174).

In general, the available literature mentioned above concurs with this idea. Brazilian foreign policy would have been formulated within the narrow sphere of Itamaraty, in a top-down manner, without taking into consideration the demands of other players from the government and from society. Thus, Faria $(2008,80)$ states, "the isolation, in which Brazilian foreign policy used to be formulated, strongly centered in Itamaraty, has been widely acknowledged." Likewise, Cason and Power $(2009,120)$ understand that "Itamaraty has maintained an impressive degree of bureaucratic autonomy and isolation".

This decision-making pattern would have been changed around the mid1980 's due to the redemocratization of the country, and especially during the 1990 's, with the impact of globalization (Armijo and Kearney 2008). Faria, Lopes and Casaróes $(2013,4)$, in this regard, sustain that "the pluralization of societal and bureaucratic agents with an interest and a stake in Brazil's international politics come up, therefore, as the most sensitive exogenous movements against the alleged monopoly Itamaraty enjoys over foreign policy-making”. Figueira $(2010,20)$ states that "the increasing participation of other players in foreign policy issues is generating a change in the foreign policy decision-making pattern in Brazil, previously characterized as highly isolated and centered in Itamaraty". The horizontalization or democratization argument is based on empirical studies that focus on specific international negotiations, as well as on changes taking place in the international system. Theoretically, part of the literature on the analysis of foreign policy and on international political economy (particularly Putnam 1988; Milner 1997; Martin 2000) is taken into consideration to sustain that the Brazilian bargaining power in international negotiations is strengthened by the openness of the state apparatus to society, the diverse preferences within the executive power and its interactions with the legislature.

An influential work about democracy and foreign policy in Brazil is the study by Lima (2000). One of the author's arguments is that "the dilution of the internal-external border may have democratic effects on the foreign policy decision-making process". The text is cautious not to establish a direct causal link between globalization, democratization and changes in the formulation of foreign policy. The study test the hypothesis about the consequences of systemic 
changes (political and economic liberalization) to the domestic sphere. This can also be seen in research projects that analyze the formulation of Brazil's position regarding litigation in the WTO Dispute Settlement Body, the participation of the Brazilian Congress in foreign policy and the implementation of South-South cooperation agreements, among others (Oliveira and Moreno 2007; Lopes 2008; Diniz and Ribeiro 2008; Faria, Nogueira and Lopez 2013). These works highlight the emergence of new stakeholders, driven by the country's redemocratization and by a closer connection between domestic issues and the international arena.

A seminal work on the thesis of horizontalization is the research carried out by França and Badin (2010). The authors studied which federal government bodies have legal competence in foreign policy. One of the conclusions is that " $50 \%$ of the bodies of the presidency and the ministries can act in the foreign policy-making arena". This would contradict "the idea about the centralization or even the insulation of the Ministry of Foreign Affairs". A note of caution in the text is that the authors recognize that their findings do not have a basis for comparison - which did not prevent them from arriving at conclusions about changes in the decision-making process. Using the same argument, Cason and Power (2009: 118) considered that the decline of Itamaraty as a consequence of the increasing number of players, the democratization process and a greater interference of the presidency (Cason and Power, 2009: 134). On foreign trade, the arguments are quite similar. According to Armijo and Kearney (2008 1012), trade policymaking process, "despite now being de facto overseen by the famously aristocratic and aloof Foreign Ministry [Itamaraty], is notably more transparent and widely consultative than in several decades".

The argument of horizontalization is not restricted to the academic world. The former head of Itamaraty, Luiz Alberto Figueiredo (2014), stated, "one of the most significant developments of Brazilian democracy has been the increasing interest of society in foreign policy issues". He also argues that it "is essential a greater involvement in foreign policy issues on the part of the National Congress, the judiciary, other ministries and government bodies, universities, the press, social movements, business, trade unions and the general public". This would provide "an increasingly broad and plural public debate, which greatly benefits the Brazilian government and Itamaraty in particular". Such arguments are not new. Sebastião do Rego Barros $(1998,18)$, Secretary-General of Itamaraty during the Fernando Henrique Cardoso (FHC) administration, referring to his early years in office, declared that there has been a "closer relationship between the institution and society". Itamaraty sought "to deepen the exchange with social organizations, parliamentarians, state and municipal governments, businessmen, trade unionists, NGOs and the press". President FHC himself participated in this debate. According to him, "in recent decades the country has changed in at least three fundamental dimensions, which had important consequences for the foreign policy. Firstly, Brazil changed from an authoritarian regime to democracy. 
Secondly, Brazil opened its markets significantly, reducing tariffs and cutting down non-tariff barriers. Thirdly, Brazil managed to stabilize its currency, after decades of inflation out of control" (Cardoso 2001, 6). As we presented above, the first two dimensions referred to by FHC have strongly influenced academic literature on the analysis of Brazilian foreign policy, particularly in the relationship between democratization and horizontalization and in the conclusion that the current situation is different than the past.

\section{Assessing the thesis of horizontalization}

\section{Conceptual accuracy}

Is horizontalization a process or a situation? Is it an ideal type or does it relate to a real situation? Does it mean changes in legal competence? Participating in the decision-making process? Influencing? Does it imply the existence of an advisory body on international issues in any institution other than Itamaraty? Does it mean participating in delegations abroad? Alternatively, would it mean the participation of non-governmental players in the decision-making process? Does it mean introducing new themes on the agenda? The answers to each of these questions imply very different definitions and obviously different research designs and conclusions. Currently, there is no or little concern about these questions. It is not clear what "horizontalization" really means. As we observed in the last session, some use the term to explain the widening authority of government agencies in the field of foreign policy; others, to counter the normative argument that Itamaraty should embrace all foreign policy activities; and several others to link the decision-making process to the nature of the political regime. It is essential, therefore, to put more effort into this preliminary activity. After defining the concept, it is necessary to clarify the variables by which one can identify whether a horizontalization process has actually taken place or not. Using the example of Pennings et al. (2006, 28), a concept (electoral volatility), must have a unit of observation (elections) and a unit of measurement (aggregate change of votes). It is important to have some sort of definition. This is extremely relevant, because the external validity of any research project presupposes a common conceptual code that reaches beyond the boundaries of individual contributions.

Horizontalization is certainly not new if conceived as the participation of other government bureaucracies in the foreign policy decision-making process. Within the issue-area of the formulation of the Brazilian positions in multilateral trade negotiations, horizontalization is historically robust (Farias 2012). But the participation of domestic players other than Itamaraty is variable in terms of institutional mechanisms and means of action, so that a mere formal and legal analysis may be insufficient to assess "horizontalization" in terms of the effective influence exerted by other actors. In many cases, participation was only pro forma; 
in other cases, the influence exerted was decisive even without formal participation (Farias and Ramanzini Júnior 2010; Ramanzini Júnior and Mariano 2013). Another question to examine is the fact that the Brazilian government today, with over three dozen ministries, is greater than ever before in the country's history - the same could be stated about the number or organized actors in society. It is natural, therefore, that the absolute number of players in the political arena is currently larger - which does not necessarily mean qualitative ruptures in decision-making patterns.

Despite a non-existing inter-bureaucratic routine of meetings, the influence of other actors in the decision-making process can be exerted through e-mails and phone calls. George and Bennett (2005) show that consultation is useful: a) for information and guidance before making a decision; b) for emotional support; c) in order to facilitate the future acceptance of decisions to be taken; d) to create consensus; e) to satisfy the expectation that a particular decision was made taking into account the positions of all relevant players, and finally, f) for a hypothetical construction of narratives. The interesting point here is that the intense flow of interactions does not necessarily reduce Itamaraty's role in the decision-making process. Andrew Hurrell and Amrita Narlikar reached similar conclusions. For them,

Brazilian foreign and foreign economic policy for much of the period after 1985 appeared to go against expectations that democratization and economic liberalization would lead naturally and easily to an increase in the pluralism of the foreign policy-making process and a greater role for societal actors. Indeed, much of the literature has underlined the limited influence of business and interest groups over economic policy in general and trade policy in particular (...) And yet it is the limits to interest-group input and involvement that are still most striking. (2006, 427-428)

We should also pay attention to the fact that diplomats have great sway outside Itamaraty. They have founded or led private organizations in Rio de Janeiro and Sáo Paulo (usually after retiring), and are active in other government agencies. Ambassador Rubens Barbosa is currently the president of the High Council on Foreign Trade of the influential Federação das Indústrias do Estado de São Paulo. Likewise, the Centro Brasileiro de Relaçóes Internacionais, the 35th best think-tank outside the United States in 2014, according to Go To Think Tank, is currently presided by ambassador Luiz Augusto de Castro Neves. In the government, fiftyfour diplomats advise the most important sectors of the bureaucracy. Forty-six Itamaraty employees work directly or indirectly in the Presidency (MRE 2015, 66-72). Excluding the case of those retired, when it comes to inter-bureaucratic conflicts, it is reasonable to assume that they will hardly oppose a higher rank colleague. The reason is the hierarchical nature of the diplomatic corps, and the need to receive the support of colleagues to advance in the career - one of the 
first phases in the promotion process is a process of horizontal and vertical voting among diplomats. Finally, in general people are chosen to occupy such posts because their standpoints are convergent with those defended by Itamaraty. Thus, the mere existence of international areas in other organizations is an inaccurate indicator to measure horizontalization. We should also study the hypothesis that the participation of other players only takes place after Itamaraty's acquiescence, agreement or invitation. The Ministry of Foreign Affairs acts as a gatekeeper, only allowing the development of activities convergent with its preferences.

The concepts of interest, participation, control and influence tend to overlap in the horizontalization literature. Participation in meetings is often used as synonymous of influence. Generally, foreign policy decision-making involves several individuals from various organizations. However, the fact that they participate in meetings does not mean they were relevant. We should ask what actor(s) decide(s) who participate? How are they selected? Does Itamaraty has final control over the decisions? Do other actors have the power to change the initial preferences of those who conduct the process? How does the whole process shape final decisions and implementation? To answer those questions, we first have to know the starting preferences of relevant actors and then observe the final result - the position assumed by Brazil in the international arena. After, we should trace back who were involved. The importance of each player in the final decision usually is discretionary, depending on legislation, customs, alliances with sectors of society, technical knowledge and often, mere chance. Not every participant in the decision-making process has the same weight when defining the final position; hence, it is not possible to consider participation and influence as synonymous. The preferences or interests of each player should not be overlooked, in case the term horizontalization is understood as influence. If Itamaraty has the same preferences as the other institutions that participate in the decision-making process, we cannot conclude that such a correlation implies a process of either insulation or horizontalization. In addition, for each different issue and stage of an international negotiation, diverse patterns of interaction occur in the domestic decision-making process, with variable levels of participation and influence.

\section{The importance of baselines}

Detecting changes entails defining what we mean about the "current" period and also the "past"- understood as the period or time frame against which the current situation is assessed. Assessment of horizontalization, therefore, needs a more precise definition about both periods. From the analytical point of view, the selection of the period is crucial. If chosen when variations are extreme, we risk regressing to the median, or even worse: wrong inferences may be drawn by association to a selection bias (Geddes 2003, 123).

We should also have the same degree of empirical depth and analytical uniformity. Some institutions and issues had not existed until recently. Let us 
imagine, for example, a discussion on the issue of international cooperation on transnational electronic crime. How could we compare the current situation of the Brazilian decision-making to prove whether "horizontalization" is actually taking place or not in connection with such a recent phenomenon? The same goes for the institutions involved. How could we discuss the Secretariat of Policies for Women in terms of horizontalization if neither the institution nor the issue existed until recently, at least in their current form? In this sense, the debate about horizontalization can often be misleading methodologically because an essential prerequisite may be missing, that is, comparability. In order to identify similarities and differences between two or more given objects in accordance with a certain criterion it is necessary that such objects have similar features (Sartori 1994).

\section{Empirical basis}

Many studies sustain the assumption that in the past the decision-making process used to take place in an isolated manner, with high autonomy or even exclusively by Itamaraty, sometimes with no empirical basis to justify such a claim (Fugueira 2010; Campos Lima, 2012). However, even a superficial overview of the history of Brazilian foreign relations can detect numerous situations contrary to the thesis of insulation. Relevant research has shown that, during the Empire, the State Council, the Parliament and several other government bodies were very active and exerted a strong influence on the foreign policy (Cervo 1981). Various ministries and even the presidents of provinces gave instructions and communicated directly with Brazilian diplomats abroad (Mendonça, 2006). In a database of 187 events related to Brazilian foreign policy, with 1308 distinct participants from 1930 to 1964 , we found out that only 341 (26\%) were diplomats. We have hundreds of participants from other branches of the government and also from society (professors, industrialists, journalists, farmers, unions, local politicians). This is evidence that other actors participated actively in key negotiations, commissions, meetings and delegations (Farias 2015). But were they influential? In-depth analysis of specific cases shows important instances when participation was translated into influence. And this is not limited to the database's period. At the beginning of the Republic, the army and even state police departments had great influence on decisions concerning international cooperation in the field of security, without the oversight of the Ministry of Foreign Affairs (McCann 2007). For a long period, the Ministry of Labor, and later the Ministry of Industry and Trade kept and managed trade promotion services abroad - something that nowadays the Brazilian Agency for Promotion of Exports and Investments (APEX) and the agricultural attachés have been unable to organize to an equivalent extent. In the 1950's, the country's position on the issue of international freights was determined primarily by the state-owned company Llóide. Until the 1960's, the Ministry of Finance played a predominant role at the GATT. There are also specific areas where pendular movements occurred. Soon after the Brazilian independence, representatives of 
the Foreign Affairs authority undertook the negotiations on financial loans in London, and the remuneration of Brazilian diplomats abroad. Upon the creation of the Brazilian Treasury Office in London, both activities were transferred to the Finance Ministry, a situation that lasted until the 1940's, when the financial responsibility for the Brazilian foreign service returned to Itamaraty's control. In the case of financial negotiations, such pendular variation is even greater, with periods of more or less activity and control on the part of Itamaraty. All these examples show that decision-making processes in the past may have been more complex than what we initially think ${ }^{5}$.

That is why it is important to have a proper sampling to which the present situation is compared. Regarding the aforesaid, it is relevant to quote Dahl (1958, 466):

(...) I do not see how anyone can suppose that he has established the dominance of a specific group in the community or the nation without basing his analysis on the careful examination of a series of concrete decisions. And these decisions must either constitute the universe or a fair sample from the universe of key political decisions taken in the political system. (Dahl 1958, 466, italics in the original text)

\section{Limitations on the use of sources}

Legal documents and interviews are the main sources used to justify the horizontalization argument. These are very important sources, but have limitations. Legislation is a good starting point, but reflects the legislators' standpoints and intent rather than the actual hierarchy and power relations within the government. A good example is the Foreign Trade Chamber (CAMEX). CAMEX has the legal capacity to "establish the guidelines for the negotiations of bilateral, regional or multilateral agreements and covenants relating to foreign trade", according to the competences listed in Decree $\mathrm{N}^{\circ}$ 3.981(2001). The law, however, does not create reality by itself. As Fernandes $(2013,123)$ argued, "bureaucratic conflicts and disputes was a determining factor for the institutional instability and for the consolidation of a suboptimal format, one that faces challenges in coordinating the Brazilian foreign trade". Therefore, only by means of an empirical examination of the actual performance of this body could we reach the conclusion that it works according the law (Carvalho 2010; Fernandes 2013).

In the case of interviews, we need to identify accurately the conceptual differences mentioned above. In general, many interviewees believe that the mere participation in inter-ministerial meetings or missions abroad is synonymous with

5 The cases cited are used as examples. This reservation is important because one of the aspects that we are drawing attention to is the need to find measurements or criteria for inter-temporal comparisons to overcome the arbitrary selection of cases. 
exerting influence. There is also a methodological issue. Depending on when the researcher conducts the interview, the respondent will state something different. This stems from the simple fact that the participation of the specific government body may vary depending on the stage of the domestic decision-making process and the nature of the international negotiation. It is for this reason that methods and sources should always reflect reality and its complex movements as if it were a film, rather than picturing it as the static illusion of a photograph. An interview may also show the respondent's bias. The officials and observers engaged in a given decision-making process, whose future careers depend on proving that they have been influential, are generally prone to maximize the role they played. On the other hand, those who actually influence the decision-making process need to show a bias towards democratic legitimacy even if they controlled the whole process (Seidman 2013, 44-52, 81-95; Arksey 1999, 149-173).

\section{Systemic forces}

Horizontalization might be seen as a consequence from systemic forces affecting foreign policy decision-making, such as major changes in the political regime, the process of globalization and changes in the international system. Such processes would have a causal effect, generating a growing diversification of actors participating in the formulation of Brazilian foreign policy, plus a decrease of the relative importance of Itamaraty ${ }^{6}$. The adaptive responses of Itamaraty to this situation, however, is seldom taken into consideration. Moreover, the following arguments tend to be disregarded: firstly, that globalization, understood as an accelerated integration of international markets, and its impact on the state apparatus is a dynamic process that has been under way since at least the 19th century; secondly, the fact that Brazil had previously undergone processes of redemocratization.

We should also not overestimate the power of systemic variables. These forces do not exert a direct and one-dimensional impact on the bureaucratic apparatus of the state. As shown in the wide literature on the subject (Arceneaux and PionBerlin 2005; Gourevitch 1978; Haggard 1990; Velasco and Cruz 2007), it is possible to have consequences which are unforeseeable or contrary to what was expected, depending on the interaction of ideas, policies, institutions and legacies of previous processes. That is why it is important to be empirically aware of how effectively these forces impact the state apparatus, avoiding generic statements with shallow cause and effect links.

6 In this regard, it is pertinent to consider the argument by Hocking (1999, 14), "the image of foreign ministries suffering from a state of terminal decline perhaps is a distortion of reality. (...) [T] his is due in part to a misreading of the nature and historical evolution of foreign ministries and their relations with other government agencies in the management of international policy". 


\section{Conclusion}

In the second edition of his book about democracy in Latin America, Peter $\mathrm{H}$. Smith argued that one of the great challenges for Latin American democracies is the current level of dissatisfaction with local governments (Smith 2012, 304-305). According to the literature reviewed in this article, part of the answer for that problem would be greater interaction between social groups and state bureaucracies in shaping public policies. In the field of Brazilian foreign policy analysis, there is an increasing awareness about this trend, showed particularly in the thesis of horizontalization of the decision-making process. We sustain that this thesis might gain from sidestepping five constraints - conceptual vagueness, lack of clarity in the baseline to which comparisons are made, lack of empirical basis, limitations on the use of sources, and overvaluation of systemic forces. As Pinheiro (2009) suggested, it is also important to analytically verify the dynamics of horizontalization both from the society and the state point of view.

To detect the existence of horizontalization in a foreign policy issue, first we must define what this term means. Second, we should understand the consequences of choosing the time frame. As Slater and Simmons argue (2010, 886) "political scientists increasingly recognize that our biggest 'why' questions cannot be adequately answered without careful attention to the question of 'when"”. Third, it is necessary to know precisely what the external position was in the base line and who determined it domestically. Provided it was defined by Itamaraty, once analyzing the second moment, we may either assume the hypothesis of horizontalization or not (if other actors were instrumental in the first moment, it is impossible to speak about a horizontalization process, unless we are referring to gradations). Finally, the decision-making processes in both moments should be comparable. It is also important to take into account the need of methodological "operationalization", i.e. "the choice of observable indicators that can be used as proxies for abstract and non-observable concepts" (Geddes 2003, 144).

A possible method to support the horizontalization thesis is the use of counterfactuals. There is an extensive literature in history and in political science on such a method; in our case, it would consist in questioning whether the Brazilian position would have been different in the absence of actors other than Itamaraty. If the answer were affirmative, we would almost certainly be investigating a decision-making process in which other actors exerted their influence, even if such participation would have been requested or simply acquiesced by Itamaraty.

Is it possible to speak about a pervasive situation of either insulation or horizontalization? This is certainly difficult. In a radical analysis, we would have to observe all foreign policy arenas to confirm one of the options, but just one case to the contrary would prove either paradigm false. On the other hand, it would be more reasonable to state that one of the options "predominantly" characterized a specific period or arena. For each one, we might find a different pattern of relationships among the actors involved and how they interact with state structures. 
There is, therefore, a wide range of situations of insulation and horizontalization. Rare are the occasions when Itamaraty makes every decision without the participation and acknowledgement of other players. Nevertheless, that can happen. On some occasions, Itamaraty and other actors involved have convergent interests; on some other there are conflicts. In situations where interests and stakes are convergent, the actors involved may abstain from participating in the decision-making process or delegate their decision-making just because they believe that their standpoints will be met. Collaboration is an interesting case, where there is a division of labor. Usually Itamaraty requests assistance from other agencies. The latter prepare the information requested, and then Itamaraty, like a gatekeeper, chooses what is relevant. This is just an example of the various types of collaboration that may take place. When there are conflicts, an interesting approach to examine the relative preponderance of actors is to use the literature on veto power (Tsebelis 2002). Although mainly used to study the relations between the legislature and the executive branch, the theory may be adapted to this situation. Thus, overcoming the simplistic dichotomy insulation/horizontalization, we should strive for a research agenda to explain the emergence of a more refined decision-making pattern. With this framework, we will broaden our knowledge about how specific patterns of domestic demands are translated into state actions in the international arena. The organization capacity of domestic groups, the level of internationalization of specific issue-areas, connection with important political actors are all helpful in understanding such dynamic. One important contribution in this direction is the book organized by Pinheiro e Milani (2012), which evaluates the interaction between government bureaucracies and society in themes such as education and culture in the foreign policy agenda after the 1980's.

One should ask exactly what dependent variable is to be explained and what independent and intervening variables make up of what we study. It is inadequate to highlight changes in a dependent variable (insulation or horizontalization) without specifying relevant independent variables (democratization, globalization, higher number of ministries, presidential leadership) or the process by which they interact. In this sense, this field of study faces a double challenge. The first is the conceptual treatment: what is horizontalization and what can be concluded about its background? This would be a descriptive inference challenge. The second challenge regards causal inference. What explains horizontalization (or the lack of it)?

Hence, when we speak about horizontalization of Brazilian foreign policymaking, we should think about how it translates in analytical terms. Is foreign policy the result of domestic decision-making? Is it the projection of this process to our international partners by our negotiators? Is it the resulting agreements and understandings that must be later approved by parliament? In any case, we must temporarily identify the domestic decision-making sphere responsible for a given decision and who executed it vis-à-vis the international counterparts. These two units are not necessarily equivalent. It is well known that a negotiator can substantially alter even objective instructions. In practical terms, even if Itamaraty is 
defeated in the domestic decision-making process, it could restructure the Brazilian position, provided Itamaraty itself is the negotiator. Nor should we forget that while other domestic actors may be victorious in the decision-making process, if the international negotiation generates a document to be approved by the legislature, Itamaraty will once again have an opportunity to intervene in the process; not to mention, of course, in the dynamics of implementation. Therefore, it is clear that on every occasion we may find a different configuration in the predominance of the players involved.

The study of foreign policy has great relevance for the broader debate on democratization in Latin America. The field usually focuses on aspects like electoral systems, term limits, state capacity, inequality, freedom of the press and judiciary and parliamentary independence. These are extremely relevant aspects, but they do not capture how citizens trust political institutions to deliver their needs. Studies on foreign policy, therefore, can improve our understanding of how Latin American states can engage citizens in shaping their own future. Due to the legacy of authoritarianism, state bureaucracies across the region still refrain from relying on the participation of citizens as a condition to good governance and legitimate public policies. This article, while examining the literature on Brazilian foreign policy, provided several routes to engage this issue, paying particular attention to how can we sidestep several theoretical and methodological pitfalls.

\section{Bibliographic references}

Arceneaux, Craig L., and Pion-Berlin, David. Transforming Latin America: the international and domestic origins of change. Pittsburgh: University of Pittsburgh Press, 2005.

Aragonès, Enriqueta, and Sánchez-Pagés, Santiago. A theory of participatory democracy based on the real case of Porto Alegre. European Economic Review, v. 53, n. 1, p. 56-72. 2009.

Arksey, Hilary, and Knight, Peter. Interviewing for social scientists: an introductory resource with examples. London: Sage Publications, 1999.

Armijo, Leslie Elliott, and Kearney, Christine. Does democratization alter the policy process? Trade policymaking in Brazil. Democratization, vol. 15: 5, 2008.

Avritzer, Leonardo. Participatory institutions in democratic Brazil. Cambridge, U.K.: Cambridge University Press, 2009.

Barros, Alexandre de S.C. The formulation and implementation of Brazilian foreign policy: Itamaraty and the new actors. In: Muñoz, Heraldo, and Tulchin, Joseph S. Latin American Nations in World Politics. Boulder: Westview Press, 1984. p. 30-44.

Booth, John A., and Seligson, Mitchell A. Images of political participation in Latin America. In: Booth, John A., and Seligson, Mitchell A. Political participation in Latin America. Volume I: citizen and state. New York: Holmes \& Meier Publishers, 1978. p. 3-33.

Brasil, Flávia De Paula Duque; Carneiro, Ricardo, et al. Participação, desenho institucional e alcances democráticos: uma análise do Conselho das Cidades (CONCIDADES). Revista de sociologia e politica, v. 21, n. 48, p. 5-18, 2013. 
Bruera, Hernán F. Gómez. Participation Under Lula: Between Electoral Politics and Governability. Latin American Politics and Society. v. 57, n.2, p. 1-20, 2015.

BURGES, Sean. The new actors of Brazilian foreign policy. Brazilian Political Science Review, v. 7, n. 2, 2013.

Castro, Rafaelle de; Ferreira, Regina, et al. Participação e controle social nas políticas urbanas: avanços e limites do Conselho Nacional das Cidades. ANPOCS. Caxambu, 2011. Accessed April 27, 2014. http://www.anpocs.org.br/portal/35_encontro_gt/GT04/castro_ferreira_ santosJr_cardoso.pdf\%3E/.

Cardoso, Fernando Henrique. A política externa do Brasil no início de um novo século: uma mensagem do Presidente da República. Revista Brasileira de Politica Internacional, v. 44, n. 1, 2001.

Carvalho, Maria Izabel Valadão. Condicionantes Internacionais e Domésticos: o Brasil e o G-20 nas negociações agrícolas da Rodada Doha. Dados - Revista de Ciências Sociais, Rio de Janeiro, v. 55, n. 2, p. 405-445, 2010.

Campos Lima, Melina Moreira. Horizontalização da política externa brasileira no século XXI: um estudo das atuaçóes da Embrapa e da Fiocruz na África. Dissertação de Mestrado. UFRJ, 2012.

Carothers, Tom H. In the name of democracy: US policy toward Latin America in the Reagan years. Berkeley: University of California Press, 1991.

Cason; Jeffrey, and Power, Timothy. Presidentialization, Pluralization, and the rollback of Itamaraty: explaining change in Brazilian foreign policy making in the Cardoso-Lula era. International Political Science Review, v. 30, n. 2., p. 117-140, 2009.

Cervo, Amado Luiz. O parlamento brasileiro e as relaçôes exteriores: 1826-1889. Brasília: Universidade de Brasília, 1981.

Dahl, Robert. A critique of the ruling elite model. American Political Science Review, v. 52, n. 2, p. 463-469. 1958.

Diniz, Simone, and Ribeiro, Claudio O. The role of the Brazilian Congress in foreign policy: an empirical contribution to the debate. Brazilian Political Science Review, v. 2, n. 2008.

Drake, Paul W. Between tyranny and anarchy: a history of democracy in Latin America, 18002006. Stanford: Stanford University Press, 2009.

Eurabanks, Virginia. Participatory policy analysis. In: Dubnick, Melvin J., Bearfield, Domonic A., et al. Encyclopedia of public administration and public policy. Volume 2. Second Edition. Boca Raton: Taylor \& Francis, 2007. p. 1413-7.

Faria, Carlos Aurélio Pimenta. Opinião pública e política externa: insulamento, politização e reforma na produção da política exterior do Brasil. Revista Brasileira de Política Internacional, v. 51, n. 2, 2008.

Faria, Carlos Aurélio P; Nogueira, Joana L. M.; Lopes, Dawisson Belem. Coordenação intragovernamental para a implementação da política externa brasileira: o caso do Fórum IBAS. Dados, Rio de Janeiro, v. 55, n. 1, 2012.

Farias, Rogério De Souza. Industriais, economistas e diplomatas: o Brasil e as negociaçóes comerciais multilaterais (1946-1967). Tese de Doutorado. Brasília: Universidade de Brasília, 2012.

Farias, Rogério de Souza. Base de dados de eventos e participantes da politica externa brasileira, 1930-1964. Versão: 0.5. Accessed February 20, 2015. https://www.academia.edu/10967160/.

Farias, Rogério; Ramanzini Júnior, Haroldo. Against the tide: democratization and foreign policy in Brazil. In: 7 Encontro Nacional da Associação Brasileira de Ciência Política (ABCP), Recife, 2010. 
Fernandes, Ivan Filipe de Almeida Lopes. A construção institucional da política comercial brasileira: a Câmara de Comércio Exterior (CAMEX) no governo Cardoso. Revista de Sociologia e Politica, v. 21, n. 45, p. 123-148, 2013.

Figueira, Ariane Roder. Rupturas e Continuidades no padrão organizacional e decisório do Ministério das Relaçóes Exteriores. Revista Brasileira de Politica Internacional, v. 53, n. 2, 2010.

Figueiredo, Luiz Alberto Machado. Diálogos sobre política externa. Folha de São Paulo. Tendências/Debates, p. A3, 26 de fevereiro de 2014.

Fuks, Mário. Participação e influência política no Conselho Municipal de Saúde de Curitiba. Revista de Sociologia e Politica, v. 25, n. 1, p. 47-61, 2005.

Geddes, Barbara. Paradigms and sand castles: theory building and research design in comparative politics. Ann Arbor: University of Michigan Press, 2003.

George, Alexander; Bennett, Andrew. Case Studies and Theory Development in the Social Sciences. Cambridge, Massachusetts: The MIT Press, 2005.

Giacalone, Rita. Latin American Foreign Policy Analysis: External Influences and Internal Circumstances. Foreign Policy Analysis, v. 8, n. 4, p. 335-54, 2012.

Gourevitch, Peter. The second image reversed: the international sources of domestic politics. International Organization, v. 32, n. 4, 1978.

Haggard, Stephen. Pathways from the Periphery. Ithaca, NY: Cornell University Press, 1990.

Hirst, Monica. The Foreign Policy of Brazil: from the democratic transition to its consolidation. Rio de Janeiro. Mimeo. 1996.

Hocking, Brian. Foreign Ministries: change and adaptation. New York: St. Martin’s Press, 1999.

Hurrell, Andrew, And Narlikar, Amrita. A New politics of confrontation? Brazil and India in multilateral trade negotiations. Global Society, 20(4): 415-433, 2006.

Levitsky, Steven, And Way, Lucan. International linkage and democratization. Journal of Democracy, v. 16, n. 3, p. 20-34. 2005.

Lijphart, Arend, And Waisman, Carlos H. (eds.).Institutional design in new democracies. Boulder: Westview, 1996.

Lima, Maria Regina Soares De. Instituições democráticas e política exterior. Contexto Internacional. V. 22, No 2,2000.

Lopes, Dawisson B. A plausibilidade de uma gestão democrática da política externa: algumas hipóteses (insatisfatórias) sobre o caso brasileiro. Cena Internacional, v. 10, n. 2, 2008.

Lowenthal, Abraham F. Exporting democracy: the United States and Latin America. Baltimore: Johns Hopkins University Press, 1991.

Knack, Stephen. Does foreign aid promote democracy? International Studies Quarterly, v. 48, n. 1, p. 251-66. 2004.

Martin, Lisa. Democratic Commitments: Legislatures and International Cooperation. Princeton: Princeton University Press, 2000.

Mccann, Frank D. Soldados da pátria: história do exército brasileiro, 1889-1937. São Paulo: Companhia das Letras, 2007.

Mendonça, Renato. Um diplomata na corte de Inglaterra. Brasília: Senado Federal, 2006. 
Milner, Helen V. Interests, institutions and information. Domestic politics and international relations. New Jersey. Ed. Princeton University Press, 1997.

MRE. Lista de Ramais - janeiro. Brasília: Ministério das Relaçóes Exteriores, 2015.

O’Donnell, Guillermo. Delegative democracy. Journal of Democracy, v. 5, n. 1, p. 55-69. 1994.

O'Donnell, Guillermo. Reflections on Contemporary South American Democracies. Journal of Latin American Studies, v. 33, n. 3, p. 599-609. 2001.

Oliveira, Marcelo F., And Moreno, Fernanda V. Negociaçóes Comerciais Internacionais e Democracia: o contencioso Brasil x EUA das patentes farmacêuticas na OMC. Dados, vol. 50, no. $1,2007$.

Oxhorn, Philip. Understanding the vagaries of civil society and participation in Latin America. In: Kingstone, Peter, and Yashar, Deborah J. Routledge handbook of Latin American politics. 2012: Routledge, 2012. p. 249-61.

Pennings, Paul, et al. Doing research in political science: an introduction to comparative methods and statistics.2nd edition. London: Sage, 2006.

Pinheiro, Leticia. Autoria y participación en la política exterior brasileña. Foreign Affairs Latino America, v. 9, n. 2, 2009.

Pinheiro, Leticia, and Milani, Carlos R. S. Introdução. In: Pinheiro, Leticia, and Milani, Carlos R. S. Politica externa brasileira: as práticas da politica e a politica das práticas. Rio de Janeiro: FGV, 2012, p. 13-32.

Putnam, Robert D. Diplomacy and Domestic Politics: The Logic of Two-Level Games. International Organization, v. 42, n. 3, 1988.

Rabe, Stephen G. Eisenhower and Latin America: the foreign policy of anticommunism. Chapel Hill: University of North Carolina Press, 1988.

Ramanzini Júnior, Haroldo, And Mariano, Marcelo P. Brazil and the G-20: domestic pressures and the construction of the negotiating position in the Doha Round of the WTO. Journal of World Trade, 47:6, 2013.

Rego Barros, Sebastião do. A execução da política externa brasileira: um balanço dos últimos 4 anos. Revista Brasileira de Politica Internacional, v. 41, n. 2, 1998.

Santos, Boaventura de Souza. Participatory budgeting in Porto Alegre: toward a redistributive democracy. In: Santos, Boaventura de Souza. Democratizing democracy: beyond the liberal democratic canon. London: Verso, 2005. p. 307-76.

Sartori, Giovani. Comparación y método comparativo. In: Sartori, Giovani; Morlino, Leonardo. La comparación em las ciências sociales. Madrid: Alianza Editorial, 1994.

Seidman, Irving. Interviewing as qualitative research: a guide for researchers in education and the social sciences. 4th. New York: Teachers College Press, 2013.

Slater, Dan, and Simmons, Erica. Informative regress: critical antecedents in comparative politics. Comparative Political Studies, 43: 886, 2010.

Schmitter, Philippe C. Transitology: the science or the art of democratization? In: Tulchin, Joseph S. e Romero, Bernice. The consolidation of democracy in Latin America. Boulder: Lynne Rienner, 1995. p. 11-45.

Smith, Peter H. Democracy in Latin America: political change in comparative perspective. 2nd edition. Oxford: Oxford University Press, 2012. 
Soares, Luis Filipe De Macedo. Política Externa e Ideologia. O Globo. 23/07/2012.

Spécie, Priscila. Política Externa e Democracia: reflexão sobre o acesso à informação na política externa brasileira a partir da inserção da temática ambiental no caso dos pneus entre o Mercosul e a OMC. Dissertação de Mestrado. Departamento de Ciência Política, USP, 2008.

Tsebelis, George. Veto players: How political institutions work. Princeton, NJ, Princeton University Press, 2002.

Velasco E Cruz, Sebastião C. Trajetórias: capitalismo neoliberal e reformas econômicas nos países da periferia. São Paulo: Editora da UNESP, 2007.

Vieira, Marco A. Brazilian foreign policy in the context of global climate norms. Foreign Policy Analysis, v. 9, n. 4, p. 369-86. 2013.

Walker, Ignacio. Democracy in Latin America: between hope and despair. Notre Dame: University of Notre Dame Press, 2013.

Wampler, Brian. Entering the State: Civil Society Activism and Participatory Governance in Brazil. Political Studies, v. 60, n. 2, p. 341-62. 2012.

Youngers, Coletta, And Rosin, Eileen. Drugs and democracy in Latin America: the impact of U.S. policy. Boulder, Colo.: L. Rienner, 2005.

\section{Abstract}

This article presents the increasing demands over the Brazilian Ministry of Foreign Affairs (Itamaraty) for opening its doors to other actors. This discussion will be followed by relevant theoretical and methodological analysis. We will defend the need to overcome problems related to: 1) conceptual vagueness about what the concept of participation means; 2) lack of clarity in the baseline to which comparisons are made; 3) fragile empirical basis; 4) limitations on the use of sources; and 5) how to understand the impact exerted by systemic forces.

Keywords: Brazilian Foreign Policy Analysis, Foreign Policy Analysis, Decision-making, Democratization, Itamaraty.

\section{Resumo}

Este artigo apresenta as demandas crescentes sobre o Ministério das Relações Exteriores do Brasil (Itamaraty) para abrir as suas portas para outros atores. Esta discussão será seguida de uma análise teórica e metodológica relevante. Vamos defender a necessidade de superar problemas relacionados a: 1) imprecisão sobre o conceito de participação; 2) falta de clareza na linha de base para que as comparações sejam feitas; 3 ) bases empíricas frágeis; 4) limitações sobre o uso de fontes; e 5) como entender o impacto exercido pelas forças sistêmicas.

Palavras-chave: Análise da Política Externa Brasileira, Análise de Política Externa, Processo decisório, Democratização, Itamaraty. 